\title{
Transfer hydrogenation of olefins catalysed by nickel nanoparticles
}

\author{
Francisco Alonso **, Paola Riente, Miguel Yus* \\ Departamento de Química Orgánica, Facultad de Ciencias and Instituto de Síntesis Orgánica (ISO), Universidad de Alicante, Apdo. 99, 03080 Alicante, Spain
}

\section{A R T I C L E I N F O}

\section{Article history:}

Received 22 September 2009

Received in revised form

14 October 2009

Accepted 15 October 2009

Available online xxx

\section{Keywords:}

Hydrogen transfer

Reduction

Olefins

Nickel nanoparticles

\section{Introduction}

The reduction of carbon-carbon double bonds is one of the fundamental reactions in organic chemistry. For this transformation, catalytic hydrogenation, either under homogeneous ${ }^{1}$ or heterogeneous ${ }^{2}$ conditions, is generally preferred to other noncatalytic chemical methods. ${ }^{3}$ Homogeneous catalysts have exhibited high activity and selectivity with special applications in asymmetric catalysis, although they are often expensive and their separation and reuse troublesome. In recent years, however, heterogeneous catalysis has experienced an enormous progress, with the catalysts being, in some cases, even more selective than their homogeneous counterparts. Moreover, heterogeneous catalysts are easy to separate and reuse, minimising the presence of metal traces in the product, improving the handling and process control and, therefore, reducing the overall costs. At any rate, catalytic hydrogenation requires special care in the handling of hydrogen (a highly flammable and explosive gas) and, in some cases, rather expensive catalysts and high pressures are mandatory for the reaction to occur.

In this sense, the hydrogen-transfer reduction of organic compounds ${ }^{4}$ is an advantageous methodology since: (a) the hydrogen source is easy to handle (no gas containment or pressure vessels are necessary), (b) possible hazards are minimised, (c) the mild reaction conditions used can afford enhanced selectivity and, (d) catalytic asymmetric transfer hydrogenation can be applied in the presence

\footnotetext{
* Corresponding author. Fax: +34 965903549.

** Corresponding author.

E-mail addresses: falonso@ua.es (F. Alonso), yus@ua.es (M. Yus).
}

of chiral ligands. In contrast with the reduction of carbonyl compounds, the hydrogen-transfer reduction of olefins has been little studied, mainly involving noble-metal catalysts. Phosphaneruthenium complexes can transfer hydrogen from alcohols, formic acid, and hydroaromatic compounds to olefins. ${ }^{5}$ Formic acid is the hydrogen donor of choice under palladium catalysis ${ }^{6 a-c}$ (1,4-cyclohexadiene has been recently used ${ }^{6 \mathrm{~d}}$ ), whereas rhodium and iridium complexes have been rarely applied. ${ }^{7}$ In the above studies, a narrow substrate scope has been tested, mainly covering activated olefins.

In the search for cheaper catalytic systems, nickel appears as an alternative to the noble metals since it is about 100 -fold cheaper than palladium and ruthenium, and much cheaper than rhodium and iridium (referred to their chlorides). As a recent example, clayentrapped nickel nanoparticles have been found to efficiently catalyse the reduction of styrenes using hydrazine as the hydrogen source. ${ }^{8}$ On the other hand, 2-propanol is a very popular hydrogen donor since it is cheap, non-toxic, volatile, possesses good solvent properties and it is transformed into acetone, which is environmentally friendly and easy to remove from the reaction system. Despite the attractiveness of the combination $\mathrm{Ni} / i-\mathrm{PrOH}$, only two reports describe its application to the transfer hydrogenation of olefins. In the first one, Raney nickel (10-50 wt \% of total substrate) was used under reflux, showing high conversions for cinnamates and cyclic olefins and low conversions for acyclic olefins. ${ }^{9}$ In the second report, activated metallic nickel, prepared by thermal decomposition of in situ generated nickel diisopropoxide in boiling 2 -propanol, was more effective in the reduction of non-functionalised and non-activated olefins $\left(10-30 \mathrm{~mol} \% \mathrm{Ni}, 95-100{ }^{\circ} \mathrm{C}\right) .{ }^{10}$

Due to our continued interest on active metals, ${ }^{11}$ some years ago, we reported that active nickel, prepared from stoichiometric 
112 Table 1

113 Hydrogen-transfer reduction of 1-octene in the presence of different nickel catalysts

114

115

116

117

118

\begin{tabular}{|c|c|c|c|c|}
\hline Entry & Ni catalyst/substrate (mmol) & $T\left({ }^{\circ} \mathrm{C}\right)$ & $t(\mathrm{~h})$ & Yield $^{\mathrm{a}}(\%)$ \\
\hline 1 & NiNPs $1: 10$ & 76 & 24 & 0 \\
\hline 2 & NiNPs $1: 5$ & 76 & 3 & 100 \\
\hline 3 & NiNPs $1: 5$ & 20 & 3 & 70 \\
\hline 4 & Raney $\mathrm{Ni}^{\mathrm{b}} 1: 5$ & 76 & 8 & 100 \\
\hline 5 & Raney $\mathrm{Ni}^{\mathrm{b}} 1: 5$ & 20 & 24 & 0 \\
\hline 6 & $\mathrm{Ni}-\mathrm{Al}^{\mathrm{b}} 1: 5$ & 76 & 24 & 0 \\
\hline 7 & $\mathrm{Ni} / \mathrm{SiO}_{2}-\mathrm{Al}_{2} \mathrm{O}_{3}{ }^{\mathrm{b}} 1: 5$ & 76 & 24 & 0 \\
\hline 8 & $\mathrm{NiO}^{\mathrm{b}} 1: 5$ & 76 & 24 & 0 \\
\hline 9 & None & 76 & 24 & 0 \\
\hline
\end{tabular}

a GLC yield.

b Commercially available catalyst.

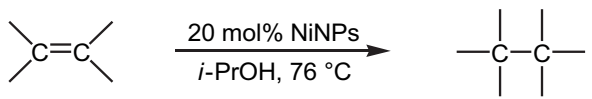

Scheme 1.

$\mathrm{NiCl}_{2} \cdot 2 \mathrm{H}_{2} \mathrm{O}$, lithium, and a catalytic amount of an arene, can effectively reduce alkenes. ${ }^{12}$ Later on, we introduced the catalytic hydrogenation of alkenes using the system $\mathrm{NiCl}_{2}$ (40 mol \%)-Li[naphthalene(cat.) or polymer-supported naphthalene(cat.)] and external molecular hydrogen. ${ }^{13}$ Alternatively, molecular hydrogen could be generated in situ from ethanol. ${ }^{14}$ More recently, we discovered that the above generated active nickel was in the form of

\section{Table 2}

Hydrogen-transfer reduction of non-functionalised alkenes catalysed by NiNPs ${ }^{\mathrm{a}}$

a Alkene ( $5 \mathrm{mmol})$, NiNPs $(1 \mathrm{mmol}), 2$-propanol $(5 \mathrm{~mL}), 76^{\circ} \mathrm{C}$

${ }^{b}$ All isolated products were $\geq 95 \%$ pure (GLC and/or ${ }^{1} \mathrm{H}$ NMR).

c GLC yield, unless otherwise stated.

d Isolated yield.

e Reported conversion with Raney nickel after $4 \mathrm{~h}$ at $80^{\circ} \mathrm{C} .{ }^{9}$ nanoparticles ${ }^{15}$ and that it was particularly active in hydrogentransfer reactions, ${ }^{16}$ namely: the $\alpha$-alkylation of methyl ketones with primary alcohols, ${ }^{16 a, b}$ the transfer hydrogenation of carbonyl compounds, ${ }^{16 c, d}$ and reductive amination of aldehydes. ${ }^{16 e}$ We wish to present herein an improved methodology for the reduction of olefins based on the catalytic transfer hydrogenation with nickel nanoparticles and 2-propanol as hydrogen donor.

\section{Results and discussion}

The nickel nanoparticles (NiNPs) were initially generated from anhydrous nickel(II) chloride, lithium powder and a catalytic amount of DTBB (4,4'-di-tert-butylbiphenyl, $5 \mathrm{~mol} \%)$ in THF at room temperature. A blank experiment, consisting in a standard reaction in the absence of the substrate but in the presence of the hydrogen source (i.e., $\mathrm{NiCl}_{2}, \mathrm{Li}, \mathrm{DTBB}, \mathrm{THF}, i$-PrOH, $76^{\circ} \mathrm{C}, 1 \mathrm{~h}$ ), confirmed the formation of NiNPs. ${ }^{17}$ Transmission electron microscopy (TEM) analysis revealed the presence of spherical and highly uniform nanoparticles within the range $0.75-2.88 \mathrm{~nm}$ (ca. $1.75 \pm 1.00 \mathrm{~nm}) .{ }^{16 \mathrm{c}}$ A preliminary study was carried out using 1 -octene as model substrate in order to optimise the amount of catalyst and compare with other nickel catalysts (Table 1). A 1:10 NiNPs/substrate molar ratio at $76{ }^{\circ} \mathrm{C}$ was shown to be inactive (entry 1 ), whereas a quantitative conversion into the product $n$-octane was observed with a 1:5 NiNPs/substrate molar ratio (20 $\mathrm{mol} \% \mathrm{Ni}$ ) (entry 2). Interestingly, the reaction occurred with the latter even at room temperature, albeit with incomplete conversion (entry 3). A series of experiments were performed with commercially available nickel catalysts. Raney nickel behaved similarly to the NiNPs but longer reaction time was needed in

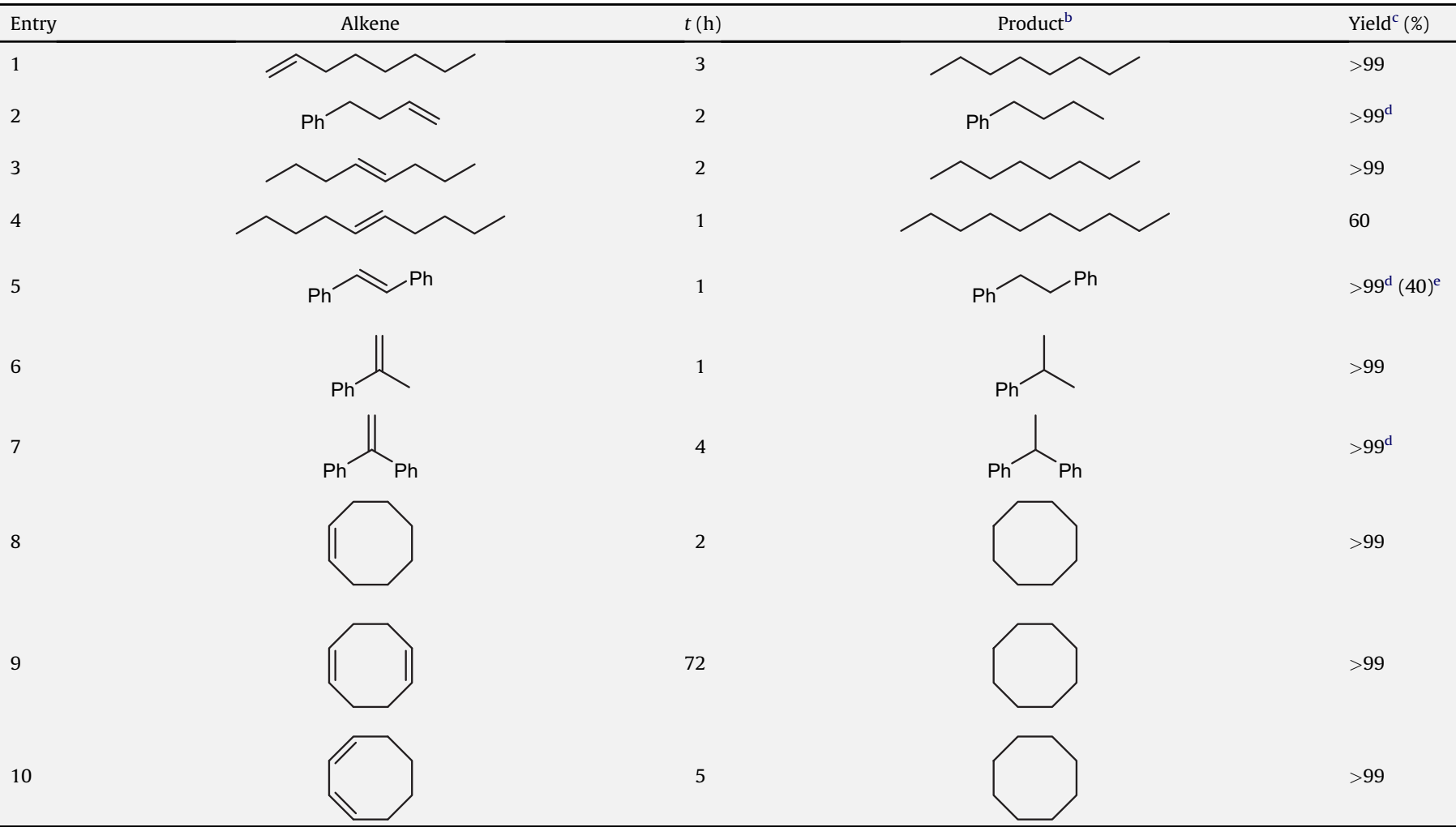


order to achieve the same conversion at $76{ }^{\circ} \mathrm{C}$ (entry 4 ), while the activity of the former drastically dropped at room temperature (entry 5). Other commercially available nickel catalysts, such as $\mathrm{Ni}-\mathrm{Al}, \mathrm{Ni} / \mathrm{SiO}_{2}-\mathrm{Al}_{2} \mathrm{O}_{3}$, or $\mathrm{NiO}$, were totally inactive under the above mentioned conditions (entries 6-8). The starting alkene was also the only reaction product when the reaction was carried out in the absence of any nickel catalyst (Li, DTBB, THF, $i$-PrOH; entry 9).

The optimised reaction conditions (Scheme 1) were first applied to a variety of non-functionalised olefins (Table 2). Terminal alkenes were easily reduced to the corresponding alkanes in quantitative yield (entries 1 and 2). The same behaviour was observed for the internal alkene trans-4-octene (entry 3), whereas trans-5-decene could not be completely reduced (entry 4). Trans-stilbene was readily and quantitatively transformed into 1,2-diphenylethane (entry 5). In contrast, only $40 \%$ conversion was achieved for the reaction catalysed by Raney nickel. ${ }^{9}$ In this case, the authors reported the formation of 1-phenyl-2-cyclohexylethane as a side product on prolonged heating (entry 5 , footnote e). Longer reaction time was needed for the geminal alkene 1,1-diphenylethene (entry 7 ) in comparison with trans-stilbene and $\alpha$-methylstyrene (entry 6 ), although the product was also obtained in excellent yield. The cyclic substrates cyclooctene, 1,5-cyclooctadiene, and 1,3-cyclooctadiene

Table 3

Hydrogen-transfer reduction of functionalised alkenes catalysed by NiNPs ${ }^{\mathrm{a}}$

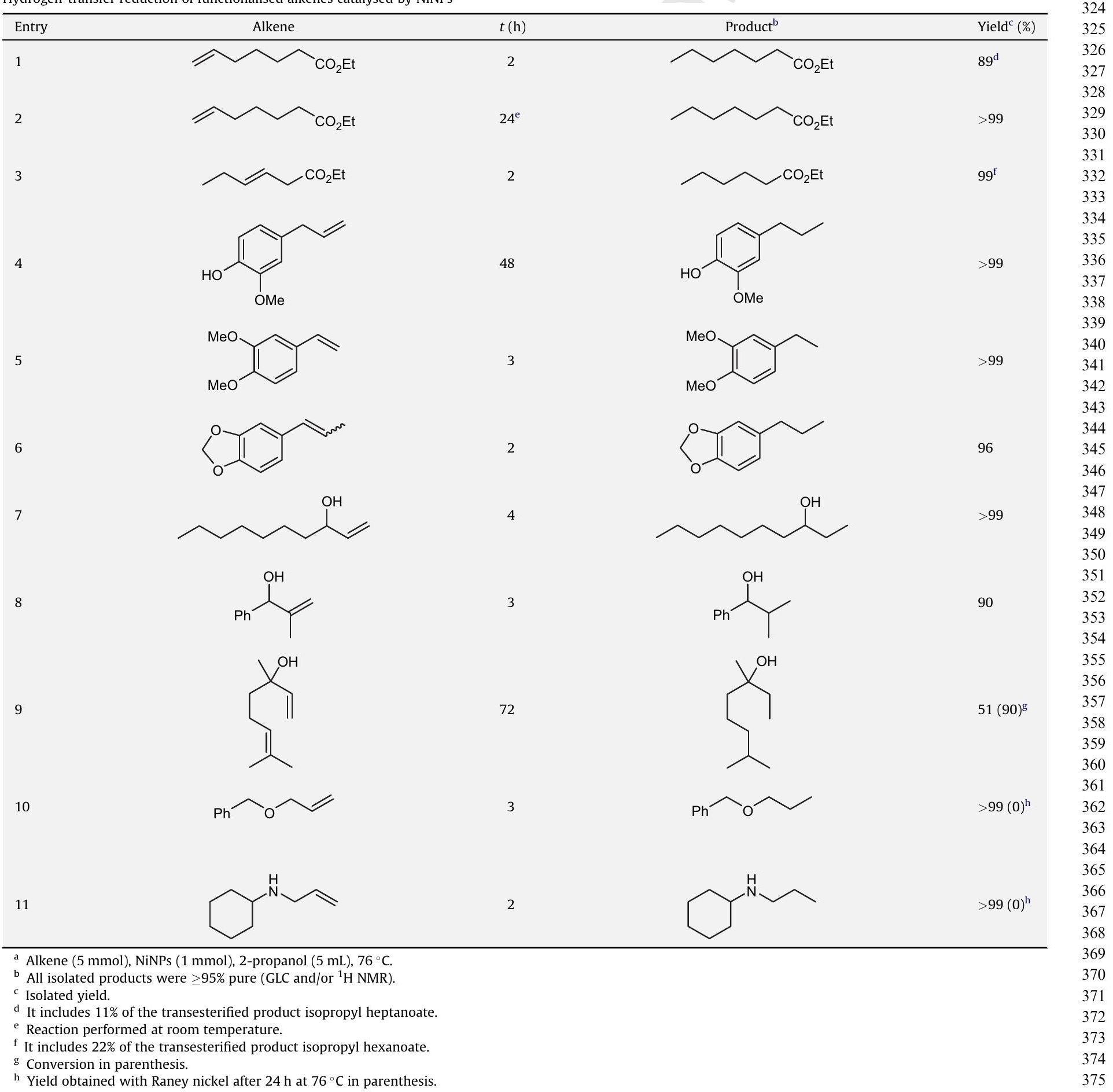

Please cite this article in press as: Alonso, F. et al., Tetrahedron (2009), doi:10.1016/j.tet.2009.10.057 
were successfully converted into cyclooctane, with the isolated diene 1,5-cyclooctadiene, a well-known ligand for $\mathrm{Ni}(0)$, being more reluctant to react.

We next studied the reduction of a series of functionalised olefins (Table 3). Both terminal and internal unsaturated esters were rapidly reduced to the corresponding saturated esters in high yields, including minor amounts of the isopropyl esters resulting from partial transesterification (entries 1 and 3). Interestingly, transesterification could be completely suppressed for ethyl 6-heptenoate when the reaction was performed at room temperature (entry 2 ). The transfer hydrogenation of 4-allyl-2-methoxyphenol was, however, rather slow, though complete conversion into the expected product was reached after prolonged heating (entry 4 ). The electron-rich aromatics 3,4-dimethoxystyrene and isosafrole were also nicely reduced in high isolated yields (entries 5 and 6). Good results were obtained for allylic alcohols, with either a monosubstituted or geminal carbon-carbon double bond (entries 7 and 8). In these cases, we did not observe any isomerisation to the corresponding carbonyl compounds. It is well known that transition-metal catalysts, some of which are also used in catalytic hydrogenation, can induce this type of isomerisation. ${ }^{18}$ In particular, the competition between hydrogenation and isomerisation of allylic alcohols over different supported palladium catalysts, including $\mathrm{Pd} / \mathrm{C}$, has been often described. ${ }^{19}$ It is noteworthy, that even the monoterpene $( \pm$ )-linalool, which contains both a mono- and a tri-substituted carbon-carbon double bond, was transformed into the saturated tertiary alcohol 3,7-dimethyloctan-3-ol (tetrahydrolinalool) in moderate yield and longer reaction time (entry 9). Apparently, this transformation is not so trivial, with most methods showing a preferential reduction of the terminal carbon-carbon double bond. ${ }^{20}$

The reduction of allyl benzyl ether and $\mathrm{N}$-allylcyclohexylamine deserves a comment aside. In both cases, the desired products were obtained in short reaction times and quantitative yields (Table 3 , entries 10 and 11). Furthermore, no deallylation products were detected despite the known ability of nickel(0) to catalyse the allyl group cleavage in ethers ${ }^{21}$ and amines. ${ }^{22}$ In addition, removal of the benzyl group in allyl benzyl ether by hydrogenolysis was prevented (entry 10). This result is very interesting if we take into account that benzyl ethers can undergo hydrogenolysis, under the same standard conditions used for the catalytic hydrogenation of olefins (e.g., $\left.\mathrm{H}_{2}-\mathrm{Pd} / \mathrm{C}, \mathrm{EtOH}\right) .{ }^{23}$ In order to know whether this special behaviour was particular for the NiNPs, a short comparative study was conducted with different nickel catalysts (Scheme 2). Raney nickel did not alter the starting material, whereas $\mathrm{Ni}(\mathrm{O}-i-\mathrm{Pr})_{2}$ afforded benzyl $n$-propyl ether in moderate yield. According to the authors, in the latter case, the substrate underwent both partial hydrogenolysis and carbon-carbon double bond migration. ${ }^{10}$ Therefore, the NiNPs were shown to be superior to Raney nickel, which besides being the most universal and commercially available nickel catalyst, we must not ignore some of its inherent disadvantages, namely: (a) the difficulty in calculating the dosage (it is usually measured as a suspension rather than weighed); (b) ferromagnetic properties that preclude the use of magnetic stirring; (c) it is potentially hazardous (pyrophoric); and (d) it becomes inactive after prolonged storage, presumably because it loses hydrogen slowly.

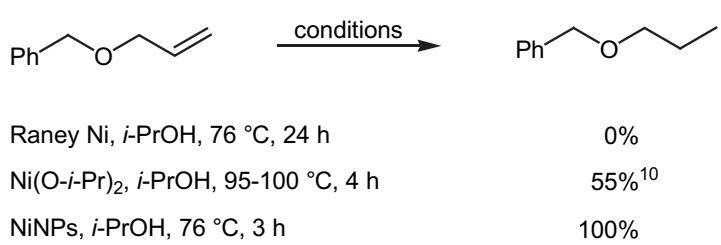

Scheme 2. Comparative transfer hydrogenation of allyl benzyl ether with different nickel catalysts.
The versatility of the NiNPs was demonstrated in the synthesis of brittonin A, a natural dihydrostilbene isolated from Frullania brittoniae subsp. truncatifolia (Fischerellq muscicola). ${ }^{24}$ We have recently reported a novel synthesis of stilbenes, from benzyl alcohols as phosphorus ylide partners, through a one-pot Wittig-type olefination reaction promoted by nickel nanoparticles. ${ }^{25}$ Resveratrol, DMU-212, and analogues have been synthesised using this methodology. ${ }^{26}$ The precursor of the target molecule, dehydrobrittonin A, is a symmetrically-substituted highly polymethoxylated stilbene that could be synthesised from only one starting material (Scheme 3). Thus, 3,4,5-trimethoxybenzyl alcohol served both as the precursor of the corresponding ylide and as its partner in the Wittig-type olefination. This reaction was shown to be slower, in comparison with the homologues with less methoxy substituents, leading to the expected stilbene in moderate yield as a mixture of diastereoisomers. Final hydrogen-transfer reduction of dehydrobrittonin A, catalysed by NiNPs, furnished brittonin A in quantitative conversion after $2 \mathrm{~h}$ and 95\% isolated yield (Scheme 3 ).

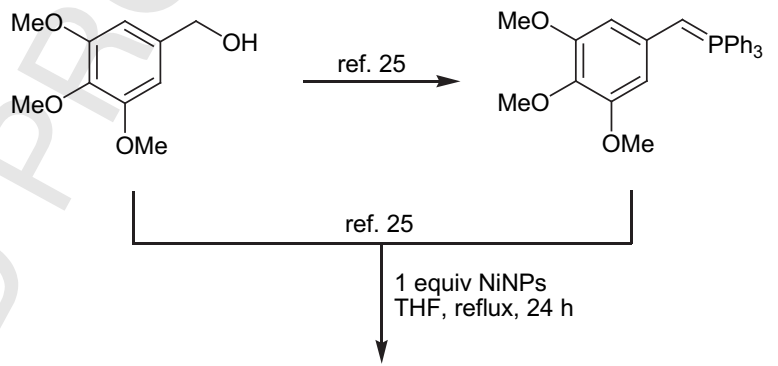<smiles>COc1cc(C=Cc2cc(OC)c(OC)c(OC)c2)cc(OC)c1OC</smiles>

dehydrobrittonin A (61\% yield, ZIE 46:54)

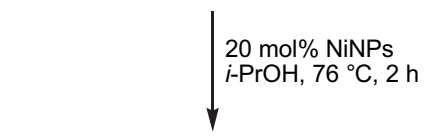<smiles>COc1cc(CCc2cc(OC)c(OC)c(OC)c2)cc(OC)c1OC</smiles>

brittonin A

(100\% conversion, $95 \%$ yield)

Scheme 3. Synthesis of the natural dihydrostilbene brittonin A.

We also studied the possibility of reutilisation of the NiNPs using trans-stilbene as the substrate. Thus, once the reaction was stopped, the NiNPs were decanted and the supernatant removed, followed by further addition of 2-propanol and the substrate. Table 4 shows that the NiNPs, in a 1:1 M ratio, could be reused over four consecutive cycles with a quantitative conversion into the reduced product. It was observed, however, that longer time was required in each cycle to reach a complete conversion. This progressive catalyst deactivation was more pronounced for a 1:5 NiNPs/substrate molar ratio, with an important decrease in the conversion being observed in the second cycle. The latter result 
differs from that obtained in the transfer hydrogenation of carbonyl compounds, where the NiNPs could be reused over five consecutive cycles with a good performance. ${ }^{16 \mathrm{~d}}$

Table 4

Reutilisation of NiNPs in the hydrogen-transfer reduction of trans-stilbene

\begin{tabular}{llllll}
\hline Run & 1 & 2 & 3 & 4 & 5 \\
\hline Yield $^{\mathrm{a}}(\%)$ & $100(1)$ & $100(1.5)$ & $100(3)$ & $100(7)$ & $16(24)$ \\
& {$[100](1)$} & {$[41](24)$} & - & - & - \\
\hline
\end{tabular}

${ }^{a}$ GLC yield after the specified time (in parenthesis) for a 1:1 NiNPs/substrate ratio. The results for a 1:5 NiNPs/substrate ratio are shown in brackets.

Concerning the reaction mechanism and based on deuterium labeling experiments, previously carried out for the transfer hydrogenation of carbonyl compounds with isopropanol, ${ }^{16 c}$ a similar dihydride-type mechanism could be invoked in this case, where the two hydrogen atoms of the donor become equivalent after being transferred to the metal to give the dihydride (Scheme 4). It must be clarified that dihydride species refer in this case to those resulting from the transfer of the two hydrogen atoms of the donor to the surface of the metal.

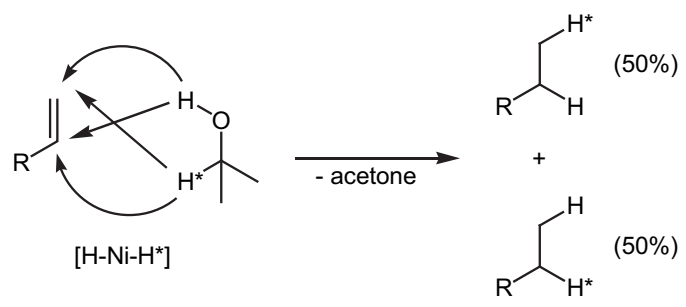

Scheme 4. Proposed dihydride-type mechanism for the transfer hydrogenation of olefins with isopropanol catalysed by NiNPs.

\section{Conclusion}

We have demonstrated, for the first time, that nickel nanoparticles can effectively catalyse the heterogeneous transfer hydrogenation of olefins using 2-propanol as the hydrogen donor. A variety of non-functionalised and functionalised olefins have been reduced in high yields. The process has been shown to be highly chemoselective for substrates, which are prone to undergo isomerisation or hydrogenolysis. Moreover, the NiNPs-catalysed transfer hydrogenation, in combination with a previous NiNPspromoted Wittig-type olefination, has been applied to the synthesis of the natural dihydrostilbene brittonin A. The transfer hydrogenation methodology presented herein is, in general, superior to others involving nickel catalysts and can be considered as an interesting alternative to other reduction methods involving noblemetal catalysts, including catalytic hydrogenation.

\section{Experimental}

\subsection{General}

THF was directly used without any purification (Acros, 99.9\%). Anhydrous nickel(II) chloride (Aldrich, 98\%), lithium powder (MEDALCHEMY S. L.), and 2-propanol (Panreac, Acros, $\geq 99.5 \%$ ) were commercially available. All the starting materials were commercially available of the best grade (Aldrich, Acros, Alfa Aesar) and were used without further purification. NMR spectra were recorded on 300 and 400 spectrometers (300 and $400 \mathrm{MHz}$ for ${ }^{1} \mathrm{H}$ NMR, and 75 and $100 \mathrm{MHz}$ for ${ }^{13} \mathrm{C}$ NMR, respectively) using $\mathrm{CDCl}_{3}$ as solvent and TMS as internal standard; chemical shifts are given in $\delta(\mathrm{ppm})$ and coupling constants $(J)$ in Hertz. Mass spectra (EI) were obtained at $70 \mathrm{eV}$, fragment ions in $m / z$ with relative intensities (\%) in parenthesis. The purity of volatile compounds and the chromatographic analyses (GLC) were determined with an instrument equipped with a flame ionisation detector and a $30 \mathrm{~m}$ capillary column $(0.32 \mathrm{~mm}$ diameter, $0.25 \mu \mathrm{m}$ film thickness), using nitrogen ( $2 \mathrm{~mL} / \mathrm{min})$ as carrier gas, $T_{\text {injector }}=275^{\circ} \mathrm{C}, T_{\text {column }}=60^{\circ} \mathrm{C}(3 \mathrm{~min})$ and $60-270^{\circ} \mathrm{C}\left(15^{\circ} \mathrm{C} / \mathrm{min}\right)$; retention times $\left(t_{r}\right)$ are given under these conditions. Thin layer chromatography was carried out on TLC plastic sheets with silica gel $60 \mathrm{~F}_{254}$ (Merck). All products in Tables 2 and 3 were characterised by comparison of their physical and spectroscopic properties with those of commercially available samples: $n$-octane (Aldrich, 111-65-9), 1(n-butyl)benzene (Aldrich, 104-51-8), n-decane (Aldrich, 124-18-5), 1,2-diphenylethane (Aldrich, 103-29-7), cumene (Aldrich, 98-82-8), 1,1-diphenylethane (Waterstone-technology-USA, 612-00-0), cyclooctane (Aldrich, 292-64-8), ethyl heptanoate (Aldrich, 106-309), ethyl hexanoate (Aldrich, 123-66-0), 2-methoxy-4-(n-propyl)phenol (Aldrich, 2785-87-7), 4-ethyl-1,2-dimethoxybenzene (ACC, 5888-51-7), 5-n-propylbenzo[d][1,3]dioxole (3B Scientific corporation, 94-58-6), decan-3-ol (Alfa Aesar, 1565-81-7), 2-methyl-1phenylpropan-1-ol (Aldrich, 611-69-8), 3,7-dimethyloctan-3-ol (Aldrich, 78-69-3), benzyl n-propyl ether (Ryan Scientific, 937-611 ), and $N$-( $n$-propyl)cyclohexanamine (Ryan Scientific, 3592-81-2). Brittonin A was characterised by comparison of its physical and spectroscopic data with those described in the literature. ${ }^{24}$

\subsection{General procedure for the NiNPs-catalysed transfer hydrogenation of olefins}

The NiNPs suspension was freshly prepared by adding nickel(II) chloride (130 mg, $1 \mathrm{mmol}$ ) over a suspension of lithium (14 mg, $2 \mathrm{mmol}$ ) and DTBB (13 $\mathrm{mg}, 0.05 \mathrm{mmol})$ in dry THF (2 mL) at room temperature under argon. The reaction mixture, which was initially dark blue, changed to black indicating that nickel $(0)$ nanoparticles were formed. After $10 \mathrm{~min}, i$-PrOH $(5 \mathrm{~mL})$ and the corresponding alkene $(5 \mathrm{mmol})$ were consecutively added. The reaction mixture was warmed up to $76^{\circ} \mathrm{C}$ and monitored by GLC-MS until total or steady conversion of the starting material. The resulting suspension was diluted with diethyl ether $(20 \mathrm{~mL})$, filtered through a pad containing Celite and the filtrate was dried over $\mathrm{MgSO}_{4}$. The residue obtained after removal of the solvent (15 Torr) was pure enough or was purified by column chromatography (silica gel, hexane or hexane/EtOAc) to give the corresponding pure alkane.

4.2.1. 1-n-Butylbenzene (Table 2, entry 2). Colourless oil; $t_{\mathrm{r}} 7.07 ; R_{f}$ 0.35 (hexane/EtOAc 95:5); $\delta_{\mathrm{H}} 0.92\left(3 \mathrm{H}, \mathrm{t}, J=5.3, \mathrm{CH}_{3}\right), 1.32-1.38(2 \mathrm{H}$, $\left.\mathrm{m}, \mathrm{CH}_{2} \mathrm{CH}_{3}\right), 1.55-1.63\left(2 \mathrm{H}, \mathrm{m}, \mathrm{CH}_{2} \mathrm{CH}_{2} \mathrm{CH}_{3}\right), 2.59(2 \mathrm{H}, \mathrm{t}, J=7.5$, $\left.\mathrm{ArCH}_{2}\right), 7.13-7.27(5 \mathrm{H}, \mathrm{m}, 5 \times \mathrm{ArH}) ; \delta_{\mathrm{C}} 13.9\left(\mathrm{CH}_{3}\right), 22.3,33.6,35.6$ $\left(3 \times \mathrm{CH}_{2}\right), 125.5,128.1,128.3(\mathrm{ArCH}), 142.8(\mathrm{ArC}) ; \mathrm{m} / z 134\left(\mathrm{M}^{+}, 3 \%\right)$, 92 (55), 91 (100), 65 (12).

4.2.2. 1,2-Diphenylethane (Table 2, entry 5). White solid; $\mathrm{mp} 51-$ $53{ }^{\circ} \mathrm{C}$ (hexane); $t_{r} 11.81 ; R_{f} 0.47$ (hexane); $\delta_{\mathrm{H}} 2.87\left(4 \mathrm{H}, \mathrm{s}, 2 \times \mathrm{CH}_{2}\right)$, 7.10-7.24 (10H, m, $10 \times \mathrm{ArH}) ; \delta_{\mathrm{C}} 37.8\left(2 \times \mathrm{CH}_{2}\right), 125.8,128.2,128.3$ $(10 \times \mathrm{ArCH}), 141.6(2 \times \mathrm{ArC}) ; \mathrm{m} / z 182\left(\mathrm{M}^{+}, 30 \%\right), 91$ (100), 65 (18).

4.2.3. 1,1-Diphenylethane (Table 2, entry 6). Colourless oil; $t_{r} 11.56$; $R_{f} 0.50$ (hexane/EtOAc 95:5); $\delta_{\mathrm{H}} 1.59\left(3 \mathrm{H}, \mathrm{d}, J=7.3, \mathrm{CH}_{3}\right), 4.09(1 \mathrm{H}, \mathrm{q}$, $\left.J=7.3, \mathrm{CHCH}_{3}\right) ; 7.09-7.24(10 \mathrm{H}, \mathrm{m}, 10 \times \mathrm{ArH}) ; \delta_{\mathrm{C}} 21.8\left(\mathrm{CH}_{3}\right), 44.7$ $\left(\mathrm{CHCH}_{3}\right), 125.9,127.5,128.2(10 \times \mathrm{ArCH}), 146.2(2 \times \mathrm{ArC}) ; \mathrm{m} / \mathrm{z} 182$ ( $\left.\mathrm{M}^{+}, 36 \%\right), 168$ (14), 167 (100), 165 (32), 152 (17), 77 (10).

4.2.4. Ethyl heptanoate (Table 3, entry 2). Colourless oil; $t_{r} 7.51 ; R_{f}$ 0.15 (hexane/EtOAc 95:5); $\delta_{\mathrm{H}} 0.88\left[3 \mathrm{H}, \mathrm{t}, \mathrm{J}=6.8,\left(\mathrm{CH}_{2}\right)_{3} \mathrm{CH}_{3}\right], 1.22-$ 1.36 [9H, m, $\left.\left(\mathrm{CH}_{2}\right)_{3} \mathrm{CH}_{3}, \mathrm{OCH}_{2} \mathrm{CH}_{3}\right], 1.59-1.63\left(2 \mathrm{H}, \mathrm{m}, \mathrm{CH}_{2} \mathrm{CH}_{2} \mathrm{CO}\right)$, $2.26\left(2 \mathrm{H}, \mathrm{t}, \mathrm{J}=7.8, \mathrm{CH}_{2} \mathrm{CH}_{2} \mathrm{CO}\right), 4.12\left(2 \mathrm{H}, \mathrm{q}, J=7.1, \mathrm{OCH}_{2} \mathrm{CH}_{3}\right) ; \delta_{\mathrm{C}} 13.7$, $13.8\left(2 \times \mathrm{CH}_{3}\right), 22.2,24.9,28.7,31.3,34.4,60.1\left(6 \times \mathrm{CH}_{2}\right), 173.8(\mathrm{CO})$; 
$640 \mathrm{~m} / \mathrm{z} 158\left(\mathrm{M}^{+}, 1 \%\right), 115$ (17), 113 (41), 101 (30), 88 (100), 85 (11), 73 641 (22), 70 (20), 61 (17), 60 (25), 55 (19).

642

4.2.5. Ethyl hexanoate (Table 3, entry 3). Colourless oil; $t_{r} 6.24 ; R_{f}$ 0.15 (hexane/EtOAc 95:5); $\delta_{\mathrm{H}} 0.89$ (3H, t, $\left.J=6.8, \mathrm{CH}_{2} \mathrm{CH}_{2} \mathrm{CH}_{3}\right), 1.22-1.36$ [7H, m, $\left(\mathrm{CH}_{2}\right)_{2} \mathrm{CH}_{3}, \mathrm{OCH}_{2} \mathrm{CH}_{3}$ ], 1.59-1.65 (2H, m, $\left.\mathrm{CH}_{2} \mathrm{CH}_{2} \mathrm{CO}\right), 2.23-$ $2.31\left(2 \mathrm{H}, \mathrm{m}, \mathrm{CH}_{2} \mathrm{CO}\right), 4.12\left(2 \mathrm{H}, \mathrm{q}, J=7.1, \mathrm{OCH}_{2} \mathrm{CH}_{3}\right) ; \delta_{\mathrm{C}} 14.1\left(2 \times \mathrm{CH}_{3}\right)$, $22.2,24.6,31.2,34.6,60.0\left(5 \times \mathrm{CH}_{2}\right), 173.8(\mathrm{CO}) ; \mathrm{m} / \mathrm{z} 144\left(\mathrm{M}^{+}, 1 \%\right), 101$ (27), 99(56), 88 (100), 73 (27), 71 (25), 70 (29), 61 (19), 60 (34), 55(23).

4.2.6. 2-Methoxy-4-(n-propyl)phenol (Table 3, entry 4). Colourless oil; $t_{r} 10.40 ; R_{f} 0.12$ (hexane/EtOAc 95:5); $\delta_{\mathrm{H}} 0.92\left(3 \mathrm{H}, \mathrm{t}, J=7.3, \mathrm{CH}_{3}\right)$, 1.54-1.64 (2H, m, $\left.\mathrm{CH}_{2} \mathrm{CH}_{3}\right), 2.49\left(2 \mathrm{H}, \mathrm{t}, J=7.8, \mathrm{ArCH}_{2}\right), 3.80(3 \mathrm{H}, \mathrm{s}$, $\left.\mathrm{CH}_{3} \mathrm{O}\right), 5.01(1 \mathrm{H}, \mathrm{s}, \mathrm{OH}), 6.63(1 \mathrm{H}, \mathrm{s}, \mathrm{ArH}), 6.65,6.80(2 \mathrm{H}, 2 \mathrm{~d}, J=8.0$, $2 \times \mathrm{ArH}) ; \delta_{\mathrm{C}} 13.7\left(\mathrm{CH}_{3}\right), 24.5,37.4\left(2 \times \mathrm{CH}_{2}\right), 55.4\left(\mathrm{CH}_{3} \mathrm{O}\right), 114.1,120.6$, $125.3(3 \times \mathrm{ArCH}), 134.3,143.2,146.3(3 \times \mathrm{ArC}) ; \mathrm{m} / z 166\left(\mathrm{M}^{+}, 23 \%\right), 137$ (100), $122(10)$.

4.2.7. 4-Ethyl-1,2-dimethoxybenzene (Table 3, entry 5). Colourless oil; $t_{r} 9.94 ; R_{f} 0.28$ (hexane/EtOAc 9:1); $\delta_{\mathrm{H}} 1.22\left(3 \mathrm{H}, \mathrm{t}, J=7.5, \mathrm{CH}_{3}\right)$, $2.59\left(2 \mathrm{H}, \mathrm{q}, J=7.5, \mathrm{CH}_{2}\right), 3.83,3.86\left(6 \mathrm{H}, 2 \mathrm{~s}, 2 \times \mathrm{CH}_{3} \mathrm{O}\right), 6.71-6.72(2 \mathrm{H}$, $55.7\left(2 \times \mathrm{CH}_{3} \mathrm{O}\right), 110.8,111.0,119.2(3 \times \mathrm{ArCH}), 136.7$ (ArC), 146.8, 148.6 (2×ArCO); $m / z 166\left(\mathrm{M}^{+}, 61 \%\right), 164$ (10), 152 (10), 151 (100), 95 (14), 91 (18), 79 (10), 77 (17).

4.2.8. 5-Propylbenzo[d][1,3]dioxole (dihydrosafrole) (Table 3, entry 6). Yellow oil; $t_{r} 9.75 ; R_{f} 0.40$ (hexane/EtOAc 95:5); $\delta_{\mathrm{H}} 0.92(3 \mathrm{H}, \mathrm{t}$, $\left.J=7.4, \mathrm{CH}_{3}\right), 1.56\left(2 \mathrm{H}\right.$, sextet, $\left.J=7.4, \mathrm{CH}_{2} \mathrm{CH}_{3}\right), 2.49(2 \mathrm{H}, \mathrm{t}, J=7.4$, $\left.\mathrm{ArCH}_{2}\right), 5.87\left(2 \mathrm{H}, \mathrm{s}, \mathrm{CH}_{2} \mathrm{O}\right), 6.58-6.72(3 \mathrm{H}, \mathrm{m}, 3 \times \mathrm{ArH}) ; \delta_{\mathrm{C}} 13.5\left(\mathrm{CH}_{3}\right)$, 24.7, 37.6, $100.5\left(3 \times \mathrm{CH}_{2}\right), 107.9,108.8,121.0(3 \times \mathrm{ArCH}), 136.4(\mathrm{ArC})$, 145.3, 147.4 (2×ArCO); m/z $164\left(\mathrm{M}^{+}, 28 \%\right), 135$ (100), 77 (17).

4.2.9. Decan-3-ol (Table 3, entry 7). Colourless oil; $t_{r} 8.64 ; R_{f} 0.42$ (hexane/EtOAc 9:1); $\delta_{\mathrm{H}} 0.86-0.96\left(6 \mathrm{H}, \mathrm{m}, 2 \times \mathrm{CH}_{3}\right), 1.03-1.55(14 \mathrm{H}$, $\left.\mathrm{m}, 7 \times \mathrm{CH}_{2}\right), 2.37(1 \mathrm{H}, \mathrm{s}, \mathrm{OH}), 3.51(1 \mathrm{H}$, quintet, $J=4.6, \mathrm{CH}) ; \delta_{\mathrm{C}} 7.8,14.1$ $\left(2 \times \mathrm{CH}_{3}\right), 22.6,23.9,29.6,30.0,31.3,31.8,36.9\left(7 \times \mathrm{CH}_{2}\right), 73.2(\mathrm{CH})$; $\mathrm{m} / \mathrm{z} 140\left(\mathrm{M}^{+}-18,21 \%\right), 129(23), 111$ (20), 97 (12), 84 (11), 83 (15), 70 (32), 69 (100), 67 (14), 59 (92), 58 (12), 57 (38), 56 (42), 55 (78), 54 (10), 53 (11).

4.2.10. 2-Methyl-1-phenylpropan-1-ol (Table 3, entry 8). Colourless oil; $t_{r} 8.84 ; R_{f} 0.16$ (hexane/EtOAc 9:1); $\delta_{\mathrm{H}} 0.76,0.97(6 \mathrm{H}, 2 \mathrm{~d}, J=6.7$, $\left.2 \times \mathrm{CH}_{3}\right), 1.85-1.94\left[1 \mathrm{H}, \mathrm{m}, \mathrm{CH}\left(\mathrm{CH}_{3}\right)_{2}\right], 2.0(1 \mathrm{H}, \mathrm{s}, \mathrm{OH}), 4.28(1 \mathrm{H}, \mathrm{d}$, $J=6.1, \mathrm{CHO}), 7.23-7.32(5 \mathrm{H}, \mathrm{m}, 5 \times \mathrm{ArH}) ; \delta_{\mathrm{C}} 18.1,18.8\left(2 \times \mathrm{CH}_{3}\right), 35.1$, $80.0(2 \times \mathrm{CH}), 126.4,127.1,128.0(5 \times \mathrm{ArCH}), 143.6(\mathrm{ArC}) ; \mathrm{m} / \mathrm{z} 150\left(\mathrm{M}^{+}\right.$, 3\%), 132 (67), 131 (16), 118 (11), 117 (100), $116(15), 115(53), 107$ (42), 105 (53), 91 (43), 79 (26), 78 (11), 77 (24), 65 (14), 63 (12), 51 (17).

4.2.11. 3,7-Dimethyloctan-3-ol (Table 3, entry 9). Colourless oil; $t_{r}$ 7.53; $R_{f} 0.19$ (hexane/EtOAc 9:1); $\delta_{\mathrm{H}} 0.87-0.90\left(9 \mathrm{H}, \mathrm{m}, 3 \times \mathrm{CH}_{3}\right), 1.16-$ $1.31\left[7 \mathrm{H}, \quad \mathrm{m}, \quad \mathrm{CH}_{3} \mathrm{C}, \mathrm{CH}_{2} \mathrm{CH}_{2} \mathrm{CH}\left(\mathrm{CH}_{3}\right)_{2}\right], 1.32-1.58 \quad[5 \mathrm{H}, \mathrm{m}$, $\left.\mathrm{CH}_{2} \mathrm{C}(\mathrm{OH}) \mathrm{CH}_{2}, \mathrm{CH}\left(\mathrm{CH}_{3}\right)_{2}\right], 2.04(1 \mathrm{H}, \mathrm{s}, \mathrm{OH}) ; \delta_{\mathrm{C}} 8.1\left(\mathrm{CH}_{3}\right), 21.5\left(\mathrm{CH}_{2}\right)$, 22.5, $26.3\left(3 \times \mathrm{CH}_{3}\right), 27.9(\mathrm{CH}), 34.1,39.5,41.5\left(3 \times \mathrm{CH}_{2}\right), 72.8(\mathrm{C}) ; \mathrm{m} / \mathrm{z}$ $140\left(\mathrm{M}^{+}-18,31 \%\right), 111$ (16), 84 (10), 83 (21), 73 (38), 71 (15), 70 (88), 69 (69), 67 (19), 57 (15), 56 (31), 55 (100), 53 (17).

4.2.12. Benzyl n-propyl ether (Table 3, entry 10). Colourless oil; $t_{r}$ 8.20; $R_{f} 0.14$ (hexane/EtOAc 95:5); $\delta_{\mathrm{H}} 0.93\left(3 \mathrm{H}, \mathrm{t}, \mathrm{J}=7.5, \mathrm{CH}_{3}\right), 1.58-$ $1.65\left(2 \mathrm{H}, \mathrm{m}, \mathrm{CH}_{2} \mathrm{CH}_{3}\right), 3.42\left(2 \mathrm{H}, \mathrm{t}, J=7.3, \mathrm{CH}_{2} \mathrm{CH}_{2} \mathrm{CH}_{3}\right), 4.49(2 \mathrm{H}, \mathrm{s}$, $\left.\mathrm{ArCH}_{2}\right), 7.24-7.26(5 \mathrm{H}, \mathrm{m}, 5 \times \mathrm{ArH}) ; \delta_{\mathrm{C}} 10.3\left(\mathrm{CH}_{3}\right), 22.7,70.9,71.9$ $\left(3 \times \mathrm{CH}_{2}\right), 127.4,127.5,128.1,128.2(5 \times \mathrm{ArCH}), 138.3(\mathrm{ArC}) ; \mathrm{m} / z 150$ (M+2\%), 92 (70), 91 (100), 79 (11), 77 (11), 65 (14).

4.2.13. $N$-(n-Propyl)cyclohexanamine (Table 3, entry 11). Yellow oil; $t_{r} 7.40 ; R_{f} 0.25$ (hexane/EtOAc 9:1); $\delta_{\mathrm{H}} 0.92\left(3 \mathrm{H}, \mathrm{t}, J=7.3, \mathrm{CH}_{3}\right), 1.01-$ $\mathrm{m}, 2 \times \mathrm{ArH}), 6.72-6.79(1 \mathrm{H}, \mathrm{m}, \mathrm{ArH}) ; \delta_{\mathrm{C}} 15.6\left(\mathrm{CH}_{3}\right), 28.2\left(\mathrm{CH}_{2}\right), 55.5$,
1.89 [13H, m, $\left.\left(\mathrm{CH}_{2}\right)_{5}, \mathrm{CH}_{2} \mathrm{CH}_{3}, \mathrm{NH}\right], 2.37-2.44(1 \mathrm{H}, \mathrm{m}, \mathrm{CH}), 2.58(2 \mathrm{H}, \mathrm{t}$, $\left.J=7.3, \mathrm{CH}_{2} \mathrm{~N}\right) ; \delta_{\mathrm{C}} 11.8\left(\mathrm{CH}_{3}\right), 23.4,25.0,26.1,33.6,48.8\left(7 \times \mathrm{CH}_{2}\right), 56.8$ (CH); $m / z 141$ (M $\left.\mathrm{M}^{+}, 19 \%\right), 112$ (47), 98 (100), 70 (12), 56 (25), 55 (14).

4.2.14. 1,2-Bis(3,4,5-trimethoxyphenyl)ethane (brittonin A) ${ }^{24}$. White solid; mp $142-143{ }^{\circ} \mathrm{C}$ (hexane); $t_{r} 19.68 ; R_{f} 0.53$ (hexane/EtOAc $7: 3) ; \delta_{\mathrm{H}} 2.85\left(4 \mathrm{H}, \mathrm{s}, 2 \times \mathrm{CH}_{2}\right), 3.83\left(18 \mathrm{H}, \mathrm{s}, 6 \times \mathrm{CH}_{3}\right), 6.36(4 \mathrm{H}, \mathrm{s}$, $4 \times \mathrm{ArH}) ; \delta_{\mathrm{C}} 38.4\left(2 \times \mathrm{CH}_{2}\right), 56.0\left(6 \times \mathrm{CH}_{3}\right), 105.3(4 \times \mathrm{ArCH}), 136.1$ ( $2 \times \operatorname{ArC}), 137.3,153.0(6 \times \operatorname{ArCO}) ; m / z 362\left(\mathrm{M}^{+}, 32 \%\right), 181$ (100).

\section{Acknowledgements}

This work was generously supported by the Spanish Ministerio de Educación y Ciencia (MEC; grant no. CTQ2007-65218; Consolider Ingenio 2010-CSD2007-00006). P.R. also thanks the MEC for a predoctoral grant.

\section{Appendix. Supplementary data}

Supplementary data associated with this article can be found, in the online version, at doi:10.1016/j.tet.2009.10.057.

\section{References and notes}

1. For reviews and monographs, see: (a) Takaya, H.; Noyori, R. In Comprehensive Organic Synthesis; Trost, B. M., Fleming, I., Eds.; Pergamon: Oxford, 1991; Vol. 8 Chapter 3.1; (b) Chaloner, P. A.; Esteruelas, M. A.; Jóo, F.; Oro, L. A. Homogeneous Hydrogenation; Kluwer Academic: Dordrecht, 1994; (c) Cui, X.; Burguess, K. Chem. Rev. 2005, 105, 3272-3296; (d) Catalysts for Fine Chemical Synthesis Roberts, S., Whittall, J., Eds.; John Wiley \& Sons: New York, NY, 2007; Vol. 5 , Chapter 2; (e) Handbook of Homogeneous Hydrogenation; de Vries, J. G., Elsevier, C. J., Eds.; Wiley-VCH: Weinheim, 2007; (f) Genet, J.-P. In Modern Reduction Methods; Andersson, P. G., Munslow, I. J., Eds.; Wiley-VCH: Weinheim, 2008 Chapter 1; (g) Diesen, J. S.; Andersson, P. G. In Modern Reduction Methods Andersson, P. G., Munslow, I. J., Eds.; Wiley-VCH: Weinheim, 2008, Chapter 2.

2. For reviews, see: (a) Siegel, S. In Comprehensive Organic Synthesis; Trost, B. M. Fleming, I., Eds.; Pergamon: Oxford, 1991; Vol. 8, Chapter 3.2; (b) Nishimura, S. Handbook of Heterogeneous Catalytic Hydrogenation for Organic Synthesis; John Wiley \& Sons: New York, NY, 2001; (c) Molnar, A.; Sarkany, A.; Varga, M. J. Mol. Catal. A: Chem. 2001, 173, 185-221.

3. For a review, see: Pasto, D. J. In Comprehensive Organic Synthesis; Trost, B. M., Fleming, I., Eds.; Pergamon: Oxford, 1991; Vol. 8, Chapter 3.3.

4. For reviews, see: (a) Johnstone, R. A. W.; Wilby, A. H. Chem. Rev. 1985, 85, 129 170; (b) Kellogg, R. M. In Comprehensive Organic Synthesis; Trost, B. M., Fleming, I., Eds.; Pergamon: Oxford, 1991; Vol. 8, Chapter 1.3; (c) Bäckvall, J.-E. J. Organomet. Chem. 2002, 652, 105-111.

5. Kitamura, M.; Noyori, R. In Ruthenium in Organic Synthesis; Murahashi, S.-I., Ed. Wiley-VCH: Weinheim, 2004; pp 31-32.

6. (a) Elamin, B.; Park, J. W.; Means, G. E. Tetrahedron Lett. 1988, 29, 5599-5600; (b) Basu, B.; Das, S.; Das, P.; Nanda, A. K. Tetrahedron Lett. 2005, 46, 8591-8593; (c) Brunel, J. M. Tetrahedron 2007, 63, 3899-3906; (d) Quinn, J. F.; Razzano, D. A.; Golden, K. C.; Gregg, B. T. Tetrahedron Lett. 2008, 49, 6137-6140.

7. (a) Spogliarich, R.; Tencich, A.; Kaspar, J.; Graziani, M. J. Organomet. Chem. 1982 , Organometallics 2007, 26, 1226-1230.

8. Dhakshinamoorthy, A.; Pitchumani, K. Tetrahedron Lett. 2008, 49, 1818-1823.

9. Andrews, M. J.; Pillai, C. N. Indian J. Chem. 1978, 16B, 465-468.

10. Boldrini, G. P.; Savoia, D.; Tagliavini, E.; Trombini, C.; Umani-Ronchi, A. J. Org. Chem. 1985, 50, 3082-3086.

11. For reviews, see: (a) Alonso, F.; Radivoy, G.; Yus, M. Russ. Chem. Bull., Int. Ed. 2003, 52, 2563-2576; (b) Alonso, F.; Yus, M. Chem. Soc. Rev. 2004, 33, 284-293; (c) Alonso, F.; Yus, M. Pure Appl. Chem. 2008, 80, 1005-1012.

12. (a) Alonso, F.; Yus, M. Tetrahedron Lett. 1996, 37, 6925-6928; (b) Alonso, F; Yus, M. J. Chem. Educ. 2001, 78, 1517-1518.

13. (a) Alonso, F.; Yus, M. Adv. Synth. Catal. 2001, 343, 188-191; (b) Alonso, F.; Candela, P.; Gómez, C.; Yus, M. Adv. Synth. Catal. 2003, 345, 275-279.

14. (a) Alonso, F.; Osante, I.; Yus, M. Adv. Synth. Catal. 2006, 348, 305-308; (b) Alonso, F.; Osante, I.; Yus, M. Synlett 2006, 3017-3020; (c) Alonso, F.; Osante, I.;

15. (a) Alonso, F.; Calvino, J. J.; Osante, I.; Yus, M. Chem. Lett. 2005, 34, 1262-1263; (b) Alonso, F.; Calvino, J. J.; Osante, I.; Yus, M. J. Exp. Nanosci. 2006, 1, 419-433.

16. (a) Alonso, F.; Riente, P.; Yus, M. Synlett 2007, 1877-1880; (b) Alonso, F.; Riente, P. Yus, M. Eur. J. Org. Chem. 2008, 4908-4914; (c) Alonso, F; Riente, P.; Yus, M. Tetrahedron 2008, 64, 1847-1852; (d) Alonso, F.; Riente, P.; Yus, M. Tetrahedron Lett. 2008, 49, 1939-1942; (e) Alonso, F.; Riente, P.; Yus, M. Synlett 2008 1289-1292.

17. The complete characterisation of the NiNPs has been recently submitted to an specialised catalysis journal. 240, 453-459; (b) Gnanamgari, D.; Moores, A.; Rajaseelan, E.; Crabtree, R. H. Yus, M. Tetrahedron 2007, 63, 93-102. 
18. For reviews, see: (a) van der Drift, R. C.; Bouwman, E.; Drent, E. J. Organomet. Chem. 2002, 650, 1-24; (b) Uma, R.; Crévisy, C.; Grée, R. Chem. Rev. 2003, 103, 27-51; (c) Cadierno, V.; Crochet, P.; Gimeno, J. Synlett 2008 $1105-1124$.

19. For a review on palladium-catalysed reactions of alcohols, including the isomerisation of unsaturated alcohols, see Muzart, J. Tetrahedron 2005, 61, 9423-9463.

20. See, for instance: (a) Widodo, A. A.; Kato, T.; Butsugan, Y. Chem. Express 1993, 8 , 701-704; (b) Shimazu, S.; Baba, N.; Ichikumi, N.; Uematsu, T. J. Mol. Catal. A Chem. 2002, 182-183, 343-350; (c) Tetrahydrolinalool has been recently obtained as major product ( $30 \%$ conversion) in the 5-ethylriboflavine-catalysed diimide reduction of linalool Smit, C.; Fraaije, M. W.; Minnaard, A. J. J. Org. Chem. 2008, 73, 9482-9485.

21. (a) Olivero, S.; Duñach, E. J. Chem. Soc., Chem. Commun. 1995, 2497-2498;

(b) Taniguchi, T.; Ogasawara, K. Angew. Chem., Int. Ed. 1998, 37, 1136-1137;

(c) Yasuhara, A.; Kasano, A.; Sakamoto, T. J. Org. Chem. 1999, 64, 4211-4213.

22. Taniguchi, T.; Ogasawara, K. Tetrahedron Lett. 1998, 39, 4679-4682.

23. Wuts, P. G. M.; Greene, T. W. Greene's Protective Groups in Organic Synthesis; Wiley-Interscience: Hoboken, 2007, pp 106-109.

24. Asakawa, Y.; Tanikawa, K.; Aratani, T. Phytochemistry 1976, 15, 1057-1059.

25. Alonso, F.; Riente, P.; Yus, M. Synlett 2009, 1579-1582.

26. Alonso, F.; Riente, P.; Yus, M. Tetrahedron Lett. 2009, 50, 3070-3073. 